\title{
ANALYSIS OF INDICATORS OF QUALITY OF LIFE DUE TO AIR POLLUTION IN SLAVONSKI BROD, CROATIA
}

\author{
IVIĆ-HOFMAN IGOR ${ }^{1} \&$ CVITKOVIĆ ANTE ${ }^{1,2}$ \\ ${ }^{1}$ Institute of Public Health of Brod-Posavina County, Croatia \\ ${ }^{2}$ Josip Juraj Strossmayer University of Osijek, Faculty of Medicine Osijek, Croatia
}

\begin{abstract}
The purpose of the paper is to analyze the data of air quality in the area of Slavonski Brod and Nova Gradiška and to test the differences between the groups of respondents in 2016 and 2017. According to the "wind indicators", the areas of exposure to polluted air were defined as "less exposed" (438 subjects), "exposed" (450) from Slavonski Brod and "non-exposed area" (286) from town Nova Gradiska. Differences in categorical indicators between groups were calculated by the hi-squared test. Research has shown statistically significant difference in the characteristics of "How healthy is your environment?" (2017) (unexposed subjects, $\mathrm{p}=0.042$ ) and "Do you believe that polluted air harms your health?" (2017) (less exposed subjects, $\mathrm{p}=0.01$ ), ie, a significant difference was found in additional features of air - odor/stench, soot or smoke, smog and dust $(\mathrm{p}<0.001)$. There were also statistically significant differences in the characteristics "assessment of quality of life" ( $\mathrm{p}=0.027)$, "environmental health" ( $\mathrm{p}<0.001)$ and "harmfulness of polluted air on health" ( $\mathrm{p}<0.001)$ ("exposed" and "nonexposed" group). Due to limited size of research sample and its frequency of certain individual states and phenomena, strength of research tests in some cases may be limited due to that fact, and therefore these research results should be interpreted with some caution.

Keywords: air pollution, quality of life, "exposed”, "less exposed”, "non-exposed” group.
\end{abstract}

\section{INTRODUCTION}

Exposure to air pollutants can affect human health in various ways, leading to increased mortality and morbidity [1], [2]. Epidemiological evidence on the health effects of air pollution is growing and evolving quickly. Today, air pollution is the largest environmental risk factor [3]. In a summary of a recent update of the WHO ambient (outdoor) air quality database states, that 3 million premature deaths occur every year as a result of exposure to outdoor air pollution, and $92 \%$ of the world's population lives in places where air quality exceeds WHO guideline limits [4]. It is also stated that in 2012, some $72 \%$ of outdoor air pollution-related premature deaths were due to ischaemic heart disease and strokes, while $14 \%$ of deaths were due to chronic obstructive pulmonary disease or acute lower respiratory infections, and $14 \%$ of deaths were due to lung cancer [5].

According to the "Annual reports on air quality in Slavonski Brod" (Croatia), the atmosphere is polluted with major pollutants $\left(\mathrm{H}_{2} \mathrm{~S}, \mathrm{PM}_{10}, \mathrm{PM}_{2.5}\right)[6]$. The Oil refinery "Brod" (Bosnia and Herzegovina) is significant contributor to the air pollution, an industrial installation located near the river "Sava", across the border with Bosnia [7]. This technologically outdated refinery was out of operation for many years. With its reestablishment nine years ago, air pollution problems started in the wider area of the city Slavonski Brod. The refinery is just across the Sava river and only $2 \mathrm{~km}$ away from Slavonski Brod in Croatia. This creates a lot of tension and the affected population is strongly protesting against pollution exceedances occurring daily during cold seasons. Accompanied with unfavourable meteorological conditions, long periods of low wind speed and stagnant air conditions, sensibility to consequences of air pollution problems became an everyday issue for local inhabitants [8]. 
Due to the air pollution in Slavonski Brod, Institute of Public Health of Brod-posavina County has conducted field research within the project "The impact of environmental factors on human health". The main goal of the project/field research is to determine more precisely, whether there is any interrelationship between air pollution factors and their posible cause of an increased morbidity or mortality rates of the citizens in Slavonski Brod and from surrounding areas. This Project will be implemented in a period of 5 years. According to the "wind indicators", and in coordination with National Institute of Meteorological and Hydrological services, the areas of exposure to polluted air were defined as "less exposed" (438 tested subjects), "exposed" (450) from Slavonski Brod (experimental groups) and "nonexposed area" (286) from town Nova Gradiska (control group) [9].

\section{PURPOSE}

The purpose of the paper is to analyze the data of air quality in the area of Slavonski Brod and Nova Gradiska and to test the differences between and within the group of subjects in 2016 and 2017. These differences are related to the statistical analysis of continuous and categorical features among tested subjects.

\section{METHODS}

Institute of Public Health of Brod-posavina County has sent collected research data for the statistical analysis, and that included a descriptive analysis of data and testing differences between groups of subjects (respondents) for the year 2016 and 2017.

A validated "Questionnaire" is used for the examination. One part of that questionnaire, referring on the "Quality of life" is taken over from World Health Organization (WHOQOLBREF) questionnaire, that measures the quality of life in multidimensional way. In some of these questions, categories were defined with the specific metric instrument, so-called "Likert scale".

Research data collection is conducted by surveying on respondents in town Slavonski Brod and one's in the area from town Nova Gradiska. Respondents from Slavonski Brod are divided into two groups, "less exposed" (value "1") and "exposed" (value "2"), while respondents from Nova Gradiska are labeled as "non-exposed" (value "0"). The statistical test model is as follows:

a) To test the differences "between" groups of respondents for 2016 and 2017.

The same respondents who participated in the research in 2016. were targeted and tested (area of Slavonski Brod) also in 2017, with the inclusion of new respondents in 2017, both from Slavonski Brod and from the area of Nova Gradiska.

"McNemar's test" is used for testing categorical features in the part of the questionnaire regarding to "Quality of life". The "Mann-Whitney test" is used to test the differences between the groups of continuous features, while the comparison of the frequency of the nominal category variables was performed with the "Chi-square test". "SPSS 23" was used for data processing.

\section{RESULTS}

The whole research during two years (2016 and 2017) included a total of 1,174 respondents, of which 450 respondents from "more exposed", 438 respondents from the "less exposed" areas, and 286 respondents from the "non-exposed" areas. For the purpose of statistical analysis, only subjects with complete medical examination and completely full-filed questionnaire were taken in statistical calculation.

In the part of the research of the "quality of life", variables of categorical features are presented as frequencies. In this sense, these categorical variables have been statistically 
processed and tested for differences: "gender", "marital status", "level of education", "working status", "smoking", "smoking of other household members", "exposure to tobacco smoke at work", "acute respiratory disease”, "malignant neoplasms", "respiratory illness", "health status", "heating on wood in household", "exposure to dust in the workplace”.

The categorical features in form of questions, that more accurately determine the "quality of life" of the respondents, which are also presented as frequencies and statistically processed by testing the differences are as follows: Q35. "How would you evaluate the quality of your life?"; Q36. "How satisfied are you with your health?"; Q37. "How healthy is your environment?"; Q38.A "Do you think that polluted air harms your health?”; Q42.A "What's bothers you with the polluted air? (smell)"; Q42.B "What bothers you related to polluted air? (soot or smoke)"; Q42.C "What bothers you related to polluted air? (smog)"; Q42.D "What bothers you related to polluted air? (pollen, weed or grass)"; Q42.E "What bothers you related to polluted air? (dust)" and Q43 "How satisfied are you with the availability of medical services?". Answers to these questions are set for "Likert scale" (two sets with five possible answers): "Very bad"; "Pretty bad", "Not good, nor bad", "Pretty good", "Very good"; and the second set of possible answers: "Not at all”, "Slightly", "Moderately", "To a great extent", "To the greatest extent".

4.1 Comparison of data between groups of respondents in 2017 - "non-exposed" to "less exposed"

One part of "quality of life" analyses included testing many of variables of categorical features for statistical differences. These differences were calculated with "Chi-square tests" and thus, they were determined between groups of respondents living in "non-exposed" areas in opposite of other subjects ("less exposed" areas), in these features: "working status" $(\chi 2=48.170, \mathrm{df}=5, \mathrm{p}<0.001 ; \mathrm{p}<0.05)$, "marital status" $(\chi 2=22.806, \mathrm{df}=5, \mathrm{p}<0.001 ; \mathrm{p}<0.05)$, "health status" $(\chi 2=7.202, \mathrm{df}=1, \mathrm{p}=0.008 ; \mathrm{p}<0.05)$ and "exposure to tobacco smoke at work" $(\chi 2=77.705, \mathrm{df}=2, \mathrm{p}<0.001 ; \mathrm{p}<0.05)($ Table 1$)$.

A statistically significant difference was identified for the features: Q36 "How healthy is your environment?" $(\mathrm{P}=0.042 ; \mathrm{p}<0.05), Q 38 A$. "Do you think that polluted air harms your health?" $(\mathrm{P}=0.010 ; \mathrm{p}<0.05)$ and for the feature $\mathrm{Q} 43$ "How satisfied are you with the availability of medical services?" ( $\mathrm{P}<0.001 ; \mathrm{p}<0.05)$. For the feature "health status of the environment", respondents from "non-exposed" areas have higher scores, while for the

Table 1: Statistical significance for the specific categorical features of "quality of life" ("Chi-square values" and "P-values") - "non-exposed" to "less exposed" group.

\begin{tabular}{|l|c|c|}
\hline & Chi-square & P-value \\
\hline "working status" (2017) & 48.170 & $<0.001$ \\
\hline "exposure on the working spot - dust" (2017) & 0.488 & 0.485 \\
\hline "marital status" (2017) & 22.806 & $<0.001$ \\
\hline "heating on wood in household" (2017) & 0.022 & 0.919 \\
\hline "acalth status" (2017) & 7.202 & 0.008 \\
\hline "smoking" (2017) & 2.157 & 0.160 \\
\hline "exposure to tobacco smoke at work" (2017) & 0.61 & 0.741 \\
\hline "smoking of other household members?" (2017) & 77.705 & $<0.001$ \\
\hline
\end{tabular}


features of "air pollution" and the "satisfaction with availability of medical services", more values show respondents from the "less exposed" areas (Table 2).

Within the feature Q42. "What's bothers you with the polluted air?", there were a statistically significant differences in the characteristics of bad "smell" ( $\chi 2=90.421, \mathrm{df}=1$, $\mathrm{p}<0.001 ; \mathrm{p}<0.05)$, "smog" $(\chi 2=4.538, \mathrm{df}=1, \mathrm{p}=0.033 ; \mathrm{p}<0.05)$, and "pollen, weed and grass" $(\chi 2=26.903, \mathrm{df}=1, \mathrm{p}<0.001 ; \mathrm{p}<0.05)$. Subjects living in the area of "less exposure" bothers more bad "smell" of polluted air, while subjects who live in the "non-exposed" area, more bothers "smog" and "pollen, weeds and grass" (Table 3).

4.2 Comparison of data between groups of respondents in 2017 - "exposed" to "nonexposed"

Analyses of statistical differences between groups of respondents living in "exposed" areas in the opposite of "non-exposed" one's, show that there are significant differences for some categorical features like: "working status" $(\chi 2=75.489, \mathrm{df}=5, \mathrm{p}<0.001 ; \mathrm{p}<0.05)$, "exposure to dust in working place" ( $\chi 2=16.302, \mathrm{df}=1, \mathrm{p}<0.001 ; \mathrm{p}<0.05)$, "marital status" $(\chi 2=21.073$, $\mathrm{df}=5, \mathrm{p}=0.001 ; \mathrm{p}<0.05)$, "heating on wood in household" $(\chi 2=23.74, \mathrm{df}=1, \mathrm{p}=0.008 ; \mathrm{p}<0.05)$ "smoking" $(\chi 2=14.555, \mathrm{df}=2, \mathrm{p}=0.001 ; \mathrm{p}<0.05)$ and "exposure to tobacco smoke at work" $(\chi 2=40.223, \mathrm{df}=2, \mathrm{p}=0.009 ; \mathrm{p}<0.05)($ Table 4$)$.

Table 2: Statistical significance for the specific features of "quality of life" - ("P-values") - "non-exposed" to "less exposed" group.

\begin{tabular}{|l|c|}
\hline & P-value \\
\hline Q35. “How would you evaluate the quality of your life?” (2017) & 0.190 \\
\hline Q36. “How satisfied are you with your health?” (2017) & 0.959 \\
\hline Q37. "How healthy is your environment?” (2017) & 0.042 \\
\hline Q38A “Do you think that polluted air harms your health?” (2017) & 0.010 \\
\hline Q43. “How satisfied are you with the availability of medical services?” & $<0.001$ \\
\hline
\end{tabular}

Table 3: Statistical significance for the specific features of "quality of life" - ("Chi-square values" and "P-values") - "non-exposed" to "less exposed" group.

\begin{tabular}{|l|c|c|c|}
\hline & $\begin{array}{c}\text { Chi- } \\
\text { square }\end{array}$ & df & P-value \\
\hline $\begin{array}{l}\text { Q42A. "What's bothers you with the polluted air?" } \\
\text { (smell) (2017) }\end{array}$ & 90.421 & 1 & 0.000 \\
\hline $\begin{array}{l}\text { Q42B. “What's bothers you with the polluted air?” } \\
\text { (soot or smoke) (2017) }\end{array}$ & 3.472 & 1 & 0.062 \\
\hline $\begin{array}{l}\text { Q42C. "What's bothers you with the polluted air?” } \\
\text { (smog) (2017) }\end{array}$ & 4.538 & 1 & 0.033 \\
\hline $\begin{array}{l}\text { Q42D. "What's bothers you with the polluted air?” } \\
\text { (pollen, weed and grass) (2017) }\end{array}$ & 26.903 & 1 & 0.000 \\
\hline $\begin{array}{l}\text { Q42E. "What's bothers you with the polluted air?” } \\
\text { (dust) (2017) }\end{array}$ & constant & constant & constant \\
\hline
\end{tabular}


Table 4: Statistical significance for the specific categorical features of "quality of life" ("Chi-square values" and "P-values") - "exposed" to "non-exposed" group.

\begin{tabular}{|l|c|c|c|}
\hline & Chi-square & df & P-value \\
\hline "working status" (2017) & 75.489 & 5 & 0.000 \\
\hline $\begin{array}{l}\text { "exposure on the working spot - dust" } \\
\text { (2017) }\end{array}$ & 16.302 & 1 & 0.000 \\
\hline "marital status" (2017) & 21.073 & 5 & 0.001 \\
\hline "heating on wood in household" (2017) & 23.74 & 1 & 0.000 \\
\hline "health status" (2017) & 2.139 & 1 & 0.150 \\
\hline $\begin{array}{l}\text { "chronic respiratory disease"(chronic } \\
\text { bronchitis) (2017) }\end{array}$ & 0.517 & 1 & 1,000 \\
\hline "acute respiratory disease" (2017) & 0.091 & 1 & 0.804 \\
\hline "smoking" (2017) & 14.555 & 2 & 0.001 \\
\hline "exposure to tobacco smoke at work" (2017) & 40.223 & 2 & 0.009 \\
\hline
\end{tabular}

In analyses of categorical features in form of questions, it is shown that there are statistically significant differences in the characteristics: Q35. "How would you evaluate the quality of your life?"; $(\mathrm{p}=0.027, \mathrm{p}<0.05)$, Q37. "How healthy is your environment?" ( $\mathrm{p}<0.001, \mathrm{p}<0.05), Q 38 A$. "Do you think that polluted air harms your health?" $(\mathrm{p}<0.001$, $\mathrm{p}<0.05)$ and the feature Q43. "How satisfied are you with the availability of medical services?" $(p<0.001, p<0.05)$.

Respondents who live in "non-exposed" area have higher values for the "assessment of quality of life" and "environmental health" feature, while for the features such are "air pollution" and the "availability of medical services", residents from "exposed" area register more values than the other ones (Table 5).

There is a statistically significant difference in the bad "smell" $(\chi 2=165.011, \mathrm{df}=1$, $\mathrm{p}<0.001 ; \mathrm{p}<0.05)$, "soot or smoke" $(\chi 2=23.216$, df $=1, \mathrm{p}<0.001 ; \mathrm{p}<0.05)$, "smog" $(\chi 2=26.984, \mathrm{df}=1, \mathrm{p}<0.001 ; \mathrm{p}<0.05)$, and "dust" $(\chi 2=4.327, \mathrm{df}=1, \mathrm{p}=0.048 ; \mathrm{p}<0.05)$ features. At all levels, the respondents from "exposed" area are more concerned about mentioned features of polluted air (Table 6).

Table 5: Statistical significance for the specific features of "quality of life" - ("P-values") "exposed" to "non-exposed" group.

\begin{tabular}{|l|c|}
\hline & P-value \\
\hline Q35. "How would you evaluate the quality of your life?" (2017) & 0.027 \\
\hline Q36. "How satisfied are you with your health?” (2017) & 0.875 \\
\hline Q37. "How healthy is your environment?" (2017) & $<0.001$ \\
\hline Q38.A "Do you think that polluted air harms your health?” (2017) & $<0.001$ \\
\hline $\begin{array}{l}\text { Q43. "How satisfied are you with the availability of medical } \\
\text { services?" }\end{array}$ & $<0.001$ \\
\hline
\end{tabular}


Table 6: Statistical significance for the specific features of "quality of life" - ("Chi-square values" and "P-values") - "non-exposed" to "exposed" group.

\begin{tabular}{|l|c|c|c|}
\hline & Chi-square & df & P-value \\
\hline $\begin{array}{l}\text { Q42A. "What's bothers you with the polluted } \\
\text { air?" (smell) (2017) }\end{array}$ & 165.011 & 1 & 0.000 \\
\hline $\begin{array}{l}\text { Q42B. "What's bothers you with the polluted } \\
\text { air?" (soot or smoke) (2017) }\end{array}$ & 23.216 & 1 & 0.000 \\
\hline $\begin{array}{l}\text { Q42C. "What's bothers you with the polluted } \\
\text { air?" (smog) (2017) }\end{array}$ & 26.984 & 1 & 0.000 \\
\hline $\begin{array}{l}\text { Q42D. "What's bothers you with the polluted } \\
\text { air?" (pollen, weed and grass) (2017) }\end{array}$ & 0.100 & 1 & 0.831 \\
\hline $\begin{array}{l}\text { Q42E. "What's bothers you with the polluted } \\
\text { air?" (dust) (2017) }\end{array}$ & 4.327 & 1 & 0.048 \\
\hline
\end{tabular}

4.3 Comparison of data between groups of respondents in 2017 - "exposed" to "less exposed"

In comparison of data between "exposed" and "less exposed" group of subjects, there is the difference in these categorical features: "exposure to dust in working place" $(\chi 2=18.694$, $\mathrm{df}=1, \mathrm{p}<0.001 ; \mathrm{p}<0.05)$, "heating on wood in household" $(\chi 2=23.065, \mathrm{df}=1, \mathrm{p}<0.001$; $\mathrm{p}<0.05)$, and "exposure to tobacco smoke at work" $(\chi 2=75.698, \mathrm{df}=2, \mathrm{p}<0.001 ; \mathrm{p}<0.05)$. (Table 7).

There is a statistically significant difference in the features "environmental health" $(\mathrm{p}<0.001, \mathrm{p}<0.05)$ and the "harmfulness of polluted air to health" $(\mathrm{p}=0.008, \mathrm{p}<0.05)$. The "less exposed" subjects have higher values for the feature "health of the environment", while the "exposed" subjects have higher scores for the feature "harmfulness of polluted air" (Table 8).

And in the final analyses, there is a statistically significant difference in "all features". Namely, respondents who are living in "exposed" area are far more concerned with problems related to contaminated air than in "less exposed" one (Table 9).

Table 7: Statistical significance for the specific categorical features of "quality of life" ("Chi-square values" and "P-values") - "exposed" to "less exposed group".

\begin{tabular}{|l|c|c|c|}
\hline & Chi-square & df & P-value \\
\hline "working status" (2017) & 3.138 & 5 & 0.684 \\
\hline "exposure on the working spot - dust" (2017) & 18.694 & 1 & $<0.001$ \\
\hline "marital status" (2017) & $0.415^{\mathrm{a}}$ & 5 & 0.996 \\
\hline "heating on wood in household" (2017) & 23.065 & 1 & $<0.001$ \\
\hline "health status" (2017) & 1.971 & 1 & 0.186 \\
\hline $\begin{array}{l}\text { "chronic respiratory disease" (chronic } \\
\text { bronchitis) (2017) }\end{array}$ & constant & constant & constant \\
\hline "acute respiratory disease" (2017) & 0.010 & 1 & 1.000 \\
\hline "smoking" (2017) & 0.162 & 2 & 0.926 \\
\hline "exposure to tobacco smoke at work" (2017) & 75.698 & 2 & $<0.001$ \\
\hline "heating on wood in household" (2017) & 1.400 & 1 & 0.271 \\
\hline
\end{tabular}


Table 8: Statistical significance for the specific features of "quality of life" - ("P-values") "exposed" to "less exposed" group.

\begin{tabular}{|l|c|}
\hline & P-value \\
\hline Q35. “How would you evaluate the quality of your life?” (2017) & 0.235 \\
\hline Q36. “How satisfied are you with your health?” (2017) & 0.616 \\
\hline Q37. "How healthy is your environment?” (2017) & 0.000 \\
\hline Q38.A “Do you think that polluted air harms your health?” (2017) & 0.008 \\
\hline Q43. “How satisfied are you with the availability of medical services?” & 0.197 \\
\hline
\end{tabular}

Table 9: Statistical significance for the specific features of "quality of life" - ("Chi-square values" and "P-values") - "non exposed" to "exposed group".

\begin{tabular}{|l|c|c|c|}
\hline & $\begin{array}{c}\text { Chi- } \\
\text { square }\end{array}$ & df & P-value \\
\hline $\begin{array}{l}\text { Q42A. "What's bothers you with the polluted } \\
\text { air?" (smell) (2017) }\end{array}$ & 4.379 & 1 & 0.044 \\
\hline $\begin{array}{l}\text { Q42B. "What's bothers you with the polluted } \\
\text { air?" (soot or smoke) (2017) }\end{array}$ & 37.616 & 1 & 0.000 \\
\hline $\begin{array}{l}\text { Q42C. "What's bothers you with the polluted } \\
\text { air?" (smog) (2017) }\end{array}$ & 39.126 & 1 & 0.000 \\
\hline $\begin{array}{l}\text { Q42D. "What's bothers you with the polluted } \\
\text { air?" (pollen, weed and grass) (2017) }\end{array}$ & 14.500 & 1 & 0.000 \\
\hline $\begin{array}{l}\text { Q42E. "What's bothers you with the polluted } \\
\text { air?" (dust) (2017) }\end{array}$ & 34.924 & 1 & 0.000 \\
\hline
\end{tabular}

\section{DISCUSSION}

Most past research studies on the health repercussions of air pollution has focused on adverse respiratory and cardiovascular disease outcomes. Only a handful of studies have examined the association of air pollution with psychological health, despite growing evidence elucidating possible mechanisms to support such a relationship [11].

In this study, some of these results give possible evidence that the presence of the Oil Refinery "Brod" (Bosnia and Herzegovina), as one of the sources of air pollution, contributes and influences at certain level on a psychological satisfaction, mental health and on overall health condition of people living close to that polluted area. Many of various research studies are speaking to the same fact, that air pollution impairs the psychological state of people in the form of dissatisfaction in numerous areas of social and health aspects of human functioning [10], [12], [14], [15]. Besides, more precisely and more in this direction of thinking, there are some animal (e.g., rodent and feral dog) and human studies, which results are suggesting that air pollution exposure may lead to neuroinflammation, oxidative stress, cerebrovascular damage, and neurodegenerative pathology via several cellular and molecular pathways [11], [13].

Through the presentation of our results, there are few facts, substantiated with statistical analysis, which show that some social determinants (expressing personal human satisfaction, health satisfaction and overall social functioning), are more present in a group of subjects who are living in "non-exposed" area, than in "less exposed" one (speaking of a better 
"working status", "marital status" and "health status"). Furthermore, respondents from "nonexposed" areas have higher scores for the feature "health status of the environment", while for the features of "air pollution" and the "satisfaction with the availability of medical services", more values show the respondents from "less exposed" areas, suggesting that subject living in the area without any remarkable source of pollution (i.e. Oil Refinery) are aware of their healthier environment, in the opposite of people in polluted areas, whose awareness on certain level of air pollution, and pollution itself could have some negative effects on their health. People who live in less "exposed" area are more bothered with bad "smell" (stink) of the air, the present fact, which could be also linked with the already mentioned source of air pollution.

Analyzing again some determinants of social behavior and personal satisfaction, between people from "exposed" and "non-exposed" area, we came across to the fact that determinants like "working status" and "marital status" are more related to the group of subjects in "nonexposed" area. Speaking of some features which are related closely to the "quality of life", like "evaluation of personal life quality" and "health status of their environment", indicate that respondents who live in "exposed area" are thinking how their personal health and environment are endangered with air pollution and they are also aware and concerned about the fact that they maybe breathe more polluted air (statistically proven significant differences in all "five" subjective varieties of air categories - bad "smell", "smog", etc.), than the subjects from "non-exposed" group.

For the final conclusion of this discussion, it should be mentioned that in comparison of data between "exposed" and "less exposed" group of subjects for feature like "health status of their environment", group of subjects from "less exposed" area have expected higher scores (thinking that they live in a more healthier environment than other groups), than the "exposed" group of respondents. On the other hand, subjects from "exposed" area stated that they live in more "air polluted" territory and they are far more concerned with problems related to contaminated air, than the respondents from the other area of this research.

\section{CONCLUSION}

Several statistically significant differences have been identified in this study. The indisputable fact is that respondents who live in "exposed" and "less exposed" areas strongly think, that their environment is at some point more polluted than the environment of subjects from "non-exposed" group. This primarily refers to the statistically proven difference for the features like "evaluation of personal life quality", "health status of their environment" and bad "smell" in the air. All of these facts point to the conclusion, that there is serious concern about people's own health status for those who are more exposed to the contaminated air in their environment.

Regarding the limitations of this research, it is important to emphasize, that the power of these conducted tests in some cases may be limited due to small sample size and lower frequency of individual states and phenomena.

\section{ACKNOWLEDGEMENTS}

Contribution to the employees of Department of Epidemiology and Public Health from "Institute of Public Health of Brod-posavina County" who collected all data for this study and special contribution to the "Croatian Institute of Public Health" for the preparation and interpretation of statistical analysis of epidemiological data. Results shown in this study are a part of the Project called "Study of impact of environmental factors on human health", which is financed by "Ministry of Health of the Republic of Croatia". 


\section{REFERENCES}

[1] Air quality guidelines: Global update 2005., Copenhagen: WHO Regional Office for Europe. http://www.euro.who.int/_data/assets/pdf_file/0005/78638/E90038.pdf. Accessed on: 23 Apr. 2018.

[2] Chen, B. \& Kan, H., Air pollution and population health: a global challenge. Environmental Health and Preventive Medicine, 13(2), pp. 94-101, 2008. DOI: http://doi.org/10.1007/s12199-007-0018-5.

[3] Methods for burden of disease attributable to ambient air pollution for the year 2012., Geneva: World Health Organization, 2014. http:/www.who.int/phe/health_topics/ outdoorair/databases/AAP_BoD_methods_March2014.pdf?ua=1. Accessed on: 24 Apr. 2018.

[4] World Health Organisation (WHO). http://www.who.int/airpollution/en/. Accessed on: 24 Apr. 2018.

[5] World Health Organisation (WHO). http://www.who.int/news-room/fact-sheets/ detail/ambient-(outdoor)-air-quality-and-health. Accessed on: 25 Apr. 2018.

[6] Godišnje izvješće za praćenje kvalitete zraka na području Republike Hrvatske za 2015, godinu, Zagreb; Hrvatska agencija za okoliš i prirodu, 2016. http://iszz.azo.hr/iskzl/ datoteka?id=31863. Accessed on: 25 Apr. 2018.

[7] Izvještaj o praćenju onečišćenja zraka na privremenoj postaji državne mreže za praćenje kvalitete zraka- Slavonski Brod (Za razdoblje 7. studenog 2013 - 8. kolovoza 2014.), Institut za medicinska istraživanja i medicinu rada: Zagreb, Jedinica za higijenu okoline. http://iszz.azo.hr/iskzl/datoteka?id=19830, Accessed on: 25 Apr. 2018.

[8] Cvitković, A. et al., Air quality and the number of urgent interventions. International Journal of Environmental Impacts, pp. 162-171. DOI: 10.2495/EI-V1-N2-162-171.

[9] Akcijski plan poboljšanja kvalitete zraka za grad Slavonski Brod, Zagreb svibanj 2016. http://slavonski-brod.hr/index.php/oneciscenje-zraka-sb/6343-savjetovanje-sazainteresiranom-javnoscu-nacrt-akcijskog-plana-poboljsanja-kvalitete-zraka. Accessed on: 26 Apr. 2018.

[10] Shin, J., Park, J.Y. \& Choi, J., Long-term exposure to ambient air pollutants and mental health status: A nationwide population-based cross-sectional study. PLOS ONE, 13(4), e0195607, 2018. DOI: https://doi.org/10.1371/journal.pone.0195607.

[11] Sass, V., Kravitz-Wirtz, N., Karceski, S.M., Hajat, A., Crowder, K. \& Takeuchi, D., The effects of air pollution on individual psychological distress. Health Place, 48 , 2017. DOI: https://doi.org/10.1016/j.healthplace.2017.09.006.

[12] Wang, Y. et al., Ambient Air Pollution and Depressive Symptoms in Older Adults: Results from the MOBILIZE Boston Study. Environmental Health Perspectives, 122(6), pp. 553-558, 2014. DOI: 10.1289/ehp.1205909.

[13] Block, M.L. \& Calderón-Garcidueñas, L., Air pollution: mechanisms of neuroinflammation and CNS disease. Trends in Neurosciences, 32(9), pp. 506-516, 2009. DOI: 10.1016/j.tins.2009.05.009.

[14] Power, M.C., Weisskopf, M.G., Alexeeff, S.E., Coull, B.A., Spiro, A. \& Schwartz, J., Traffic-related air pollution and cognitive function in a cohort of older men. Environmental Health Perspectives, 119(5), pp. 682-687, 2011.

[15] Bresnahan, B.W., Dickie, M. \& Gherkin, S., Averting behavior and urban air pollution. Land Economics, 73(3), p. 340, 1997. DOI: 10.2307/3147172. 